Discourse and Communication for Sustainable Education, vol. 11, no. 2, pp. 137-158, 2020

\title{
Examining Teachers' Culturally Relevant Education Self-Efficacy Perceptions in Turkey
}

\author{
Nihat Kotluk \\ Independent Researcher, Educational Science, Turkey \\ Serhat Kocakaya \\ Yuzuncu Yil University, Van, Turkey
}

\begin{abstract}
We designed this study with the aim to examine teachers' culturally relevant and sustaining education self-efficacy perceptions in Turkey. For this purpose, we developed a Culturally Relevant/Sustaining Education Self-Efficacy Scale. We obtained the data from 1302 teachers. Data analysis proceeded in three steps: First, we analyzed factor analysis. Second, we conducted a descriptive analysis of the items on the CRESE Scale. Finally, we compared teachers' perceptions. The scale consists of a single factor and teachers' scores on the CRESE Scale were highly reliable. The findings revealed that teachers were less efficacious in their ability to revise the teaching-learning materials in terms of cultural diversity, to give culturally relevant examples, to reflect the students' cultural values in the classroom, and to increase in school parents' and families' participation in Turkey. Also, teachers' self-efficacy perceptions differ significantly according to some variables. We discussed the implications for these findings for both further research and future teacher preparation.
\end{abstract}

Key words: culturally relevant education, self-efficacy, culturally responsive teachers.

\section{Introduction}

Almost every country, including Turkey, consists of many culturally and linguistically different (CLD) groups. With its 7 geographical regions and 81 provinces, Turkey has been the cradle for different civilizations and a place where many tribes and ethnic groups live as in every period of history. According to KONDA Research Company (2006), about $85 \%$ of people speak Turkish, $13 \%$ Kurdish and Zaza, whereas $2 \%$ of the people speak such different languages as Laz, Circassia, Armenian, Caucasian, Greek, and Arabic, in Turkey. There are 36 different ethnicities and about $78 \%$ of them are Turkish, $13 \%$ are Kurds and $1.5 \%$ are Laz. Turkey is also the largest country that received Syrian refugees in the world. The number of Syrian refugees is officially about 3.8 million and nearly 1.5 million of them are at school-age (Republic of Turkey Ministry of Interior Directorate-General for Migration Management, 2018; The United Nations Human Rights Council (UNHRC), 2018). Hence, it easily can be said Turkey is a multicultural and multilinguistic country. 
To sustain Turkey's multicultural structure, it is quite critical to guarantee equitable and culturally sensitive educational approaches to such a large number of CLD students in this country. Consequently, teacher education programs are expected to focus on preparing teachers for classrooms that are culturally and linguistically diverse. In other words, teachers are obliged to respond to cultural differences in the classes through curriculum and instruction, through teaching strategies, materials, and programs that relevant and responsive to student needs, as well as sustain-foster students' culture to improve their academic, social, and emotional development. In line with education for all and equity in education, it is important to arrange the educational process with such a way that it will include all these students in Turkey (Kotluk \& Kocakaya, 2018a; 2018 b; 2019). For some, this way to teaching CLD students is called culturally relevant pedagogy (Ladson-Billings, 1995a, 1995b, 2014; Heasly et al., 2019, 2020; Pipere, 2019); some refer to it as culturally responsive teaching (Gay, 2002, 2010, 2013, 2018); some use the title of culturally sustaining pedagogy (Paris, 2012; Paris \& Alim, 2014, 2017); or finally it may be called culturally relevant education (Aronson \& Laughter, 2016).

According to Ladson-Billings (1995a, 1995b), who is the founder of Culturally Relevant Pedagogy (CRP), a pedagogy that recognizes the importance of including students' cultural references in all aspects of learning will provide for all students despite all their differences and disadvantages. This allows students to be (a) academically successful, (b) culturally competent, and (c) will become critically conscious. On the other hand, Gay (2002) refers to the Culturally Responsive Teaching (CRT) as one of the most effective pedagogical paradigms to meet the needs of CLD students who academically fall behind their peers. Paris (2012), however, uses Culturally Sustaining Pedagogy (CSP) as a term that focuses on fostering and improving diverse cultures, languages, and aims to sustain multilingual, multicolored, and multicultural structures of society. Although delineating a difference between teaching, pedagogy, and education, we refer to an inclusive framework labeled culturally relevant education (Aronson \& Laughter, 2016) in this study. No matter which term is chosen, the goal of all these approaches is to remove the profound academic gaps between CLD students, who struggle with inequalities at school to make culturally relevant changes, and to protect and sustain such cultural diversity by preparing relevant pedagogies and culturally responsive teachers (StrekalovaHughes \& Wang, 2019).

\section{Culturally Responsive Teachers}

According to related literature, culturally responsive teachers have a positive perception of themselves and their students. They are aware of how differences such as culture, socioeconomic status, disability, and language can affect the educational process. They consider the student's culture as an important means for effective learning to take place (Ladson-Billings, 1995a). They have high expectations that all students can be successful. Culturally responsive teachers also investigate ways to learn about students' language, communities, families, and beliefs. In this way, they succeed in becoming "students' student". They can incorporate the cultures of their students into the teaching and learning content. Thus, they cooperate and learn with their students in learning environments and also help them to recognize the cultures of both themselves and others (Nieto, 2000). They have good contextual and pedagogical skills that enable them to develop different assessment practices. They create learning environments based on collaborative 
learning in all classes that cover all cultural differences. They struggle to incorporate families and parents in students' school process and stand against the negative and marginalizing attitudes and prejudices of other teachers (Ladson-Billings, 1992).

Many teacher education programs, teacher educators and researchers across the world have turned their attention towards preparing culturally relevant and responsive teachers for CLD classrooms since the 1990s (Barnes, 2006; Brown, 2007; Durden, Dooley, \& Truscott, 2016; Ellerbrock, Cruz, Vásquez, \& Howes, 2016; Gay, 2002; Lambeth \& Smith, 2016; Sleeter, 2001; Villegas \& Lucas, 2002; Vass, 2017; Warren, 2018). Siwatu (2007) stated that preparing culturally responsive teachers involves (a) equipping them with the skills needed to teach effectively, (b) increasing their culturally diverse knowledge bases, and (c) transforming teachers' multicultural attitudes. In addition to efforts to prepare these teachers, researchers have argued that teacher educators should also attend to and assess teachers' beliefs of their competence (i.e., self-efficacy) (Pajares, 2003) and there is a need for ensuring that teachers are efficacious in their ability (self-efficacy perception) to execute the practices of CRE.

\section{Self-Efficacy Perception}

According to Social Cognitive Theory (Bandura, 1977), self-efficacy is the belief that individuals can do anything and is a perception of competence rather than real competence. He precisely defined self-efficacy as, "beliefs in one's capabilities to organize and execute the courses of action required to produce given attainments" (Bandura, 1997, p. 3). The level of self-efficacy refers to the level of difficulty (low, moderate, high) individuals feel they will confront when doing a particular job and its effect on their previous positive or negative experiences, including difficulties they encountered, firsthand experiences and self-efficacy perception levels (Arseven, 2016). Hence, teachers are expected to have a high self-efficacy perception because their beliefs about having the skills and equipment necessary to guide learners to their learning do affect teaching processes.

Regarding CRE principles, CRE self-efficacy can be defined as self-efficacy beliefs that teachers can apply to evaluate all educational activities in and/or out of school, by taking into account the CLD students. This requires that teachers consider the theoretical knowledge about CRE and the differences of the students, and to reflect this knowledge in educational environments with teaching methods, techniques and strategies that are responsive to cultural values. Teachers with high CRE self-efficacy perceptions have positive attitudes, high expectations that all students with different disabilities, inadequacies, ethnic roots, racial, language, religious, and socioeconomic levels can succeed despite all their disadvantages. They have the perception that they can prepare for differences and manage the classes that hold the differences (Siwatu, 2007, 2011; Siwatu, Putman, Starker-Glass, \& Lewis, 2015). Hence, their self-efficacy beliefs in the ability to predict an individual's behavior, it appears that by examining teachers' self-efficacy beliefs in the context of this diversity, this may provide researchers with an opportunity to forecast the behavior of teachers when placed into CLD classrooms (Siwatu, Polydore, \& Starker, 2009). According to Bandura (1977), these beliefs may predict whether teachers implement CRE practices once they enter the classroom, but some researchers found out that teachers had low feelings of self-efficacy in their ability to teach in CLD classrooms (Siwatu, 2007; Siwatu, Putman, Starker-Glass, \& Lewis, 2015). 


\section{The Present Study}

Compared to other countries, teachers are trained in Turkey, as if they would encounter a single student profile throughout their professional lives, in contrast with the reality of Turkey (Aydin, 2013; Kotluk, 2018; Kotluk \& Kocakaya, 2018a, 2018b, 2019). In other words, teachers are not trained to teach in a multicultural environment in their preparatory education so that teachers and school principals have limited knowledge and skills in working with CLD students (Kotluk \& Kocakaya, 2018b). Moreover, teachers are assigned according to one exam result through a centralized system in Turkey. This means that it is highly possible for teachers to teach CLD students; therefore teachers' CRE self-efficacy perceptions are quite important when they encounter such diverse students. However, as two researchers in this study, we tried to find whether there were studies about CRE. As a result, except for some studies (Kotluk, 2018; Kotluk \& Kocakaya, 2018a, 2018b, 2019; Paksoy, 2017; Tuncel, 2017), there were no studies particularly related to CRE that inclusively examined teachers' CRE self-efficacy perceptions in Turkey. Herein lays the purpose of the current study.

Using the theoretical framework of CRE and self-efficacy theory, and in an attempt to add to the existing limited literature, the purpose of this study is threefold. First, this study provides the data necessary to begin an initial exploration of the psychometric properties and factor structure of the Culturally Relevant Education Self-Efficacy Scale. Second, this study examines teachers' culturally relevant education self-efficacy beliefs. Finally, this study examines whether teachers' self-efficacy beliefs change significantly according to some variables like gender, or teaching subjects. This study was designed to answer the following research questions.

\section{Research Questions}

1. What is the factor structure of the culturally relevant education self-efficacy scale (CRESES)?

2. How efficacious are teachers in their ability to execute the practices of CRE in Turkey?

3. Is there any statistically significant difference in teachers' self-efficacy perceptions according to the variables below?

a) The program through which they graduated;

b) The number of cities in which they have served;

c) Teaching subjects (the field of teaching);

d) Whether they have interests in, or taken courses/seminars related to multiculturalism;

e) The city they are working in;

f) The geographical area where they have spent most of their lives;

g) Gender.

\section{Methods}

\section{Participants}

In this study, we designed our research as a descriptive survey. The population of this research constitutes teachers who work in public schools of all degrees during the Fall semester of the 2017-2018 academic year in Turkey. From probability-based sampling 
methods, we used a stratified sampling method. We determined the sample in three steps. First, we identified Turkey's seven geographical regions as separate strata. Then, we determined the metropolitan municipalities, a total of 30, located in each geographical region. Second, we choose randomly seven cities in these 30 cities. We took experts' opinion for the suitability of the selected cities. Finally, we classified the schools in these seven cities according to students' socioeconomic status. After determining the sample, we printed 2700 surveys and started to obtain the data. We got back 1600 scales. But, we eliminated the scales that were marked incomplete, half-dropped, or that all the items were marked with the same choices. As a result, the sample of the study constitutes 1302 teachers working in schools located in Van, Diyarbakir, Antalya, Konya, Izmir, Istanbul and Trabzon provinces. The characteristics of the sample are given in Table 1.

Table 1

The Characteristics of Teachers in the Sample

\begin{tabular}{|c|c|c|c|}
\hline Characteristics & Category & f & $\%$ \\
\hline \multirow{5}{*}{ Program they graduate } & Teachers' Training School & 44 & 3,4 \\
\hline & Undergraduate-College & 120 & 9,2 \\
\hline & Faculty of Education & 755 & 58,0 \\
\hline & Vocational-Technical education & 87 & 6,7 \\
\hline & Faculty of Arts and Science & 296 & 22,7 \\
\hline \multirow{2}{*}{$\begin{array}{l}\text { The number of cities they } \\
\text { work in }\end{array}$} & One city & 782 & 60,1 \\
\hline & At least two cities & 520 & 27,8 \\
\hline \multirow{2}{*}{$\begin{array}{l}\text { Experiences related to } \\
\text { multicultural education }\end{array}$} & Yes & 626 & 48,1 \\
\hline & No & 676 & 51,9 \\
\hline \multirow[t]{13}{*}{ Teaching Subject* } & Pre-school Teachers & 39 & 3,0 \\
\hline & Primary School Teachers & 171 & 13,1 \\
\hline & Social Sciences Teachers & 102 & 7,8 \\
\hline & Turkish Language Teachers & 175 & 13,4 \\
\hline & Science and Technology Teachers & 150 & 11,5 \\
\hline & Foreign Languages Teachers & 139 & 10,7 \\
\hline & Information Technologies Teachers & 85 & 6,5 \\
\hline & Science Teachers & 121 & 9,3 \\
\hline & Physical Training and Sports Teachers & 52 & 4,0 \\
\hline & Arts Sciences Teachers & 24 & 1,8 \\
\hline & Vocational Courses Teachers & 62 & 4,8 \\
\hline & Psychological Counseling and Guidance & 79 & 6,1 \\
\hline & Mathematics Teachers & 103 & 7,9 \\
\hline \multirow{7}{*}{$\begin{array}{l}\text { The geographical regions they } \\
\text { mostly lived in }\end{array}$} & The Eastern Anatolia R. & 318 & 24,4 \\
\hline & The Southeastern Anatolia R. & 153 & 11,8 \\
\hline & The Mediterranean R. & 165 & 12,7 \\
\hline & The Central Anatolia R. & 171 & 13,1 \\
\hline & The Black Sea R. & 166 & 12,7 \\
\hline & The Aegean R. & 188 & 14,4 \\
\hline & The Marmara R. & 141 & 10,8 \\
\hline
\end{tabular}




\begin{tabular}{llrr} 
& & Continuation of Table 1 \\
\hline \multirow{2}{*}{ The city they serve in currently } & Van & 344 & 26,4 \\
\cline { 2 - 4 } & Diyarbakir & 210 & 16,1 \\
\cline { 2 - 4 } & Antalya & 154 & 11,8 \\
\cline { 2 - 4 } & Konya & 144 & 11,1 \\
\cline { 2 - 4 } & Trabzon & 159 & 12,2 \\
\cline { 2 - 4 } & Izmir & 159 & 12,2 \\
\cline { 2 - 4 } & Istanbul & 132 & 10,1 \\
\hline Gender & Female & 587 & 45,1 \\
\cline { 2 - 4 } & Male & 715 & 54,9 \\
\hline $\mathrm{N}$ & & 1302 & 100 \\
\hline
\end{tabular}

\section{Measures}

\section{Academic and demographic background questionnaire}

With the Academic and Demographic Background Questionnaire, we aimed to obtain information from the teachers' academic and demographic background. Included in the questionnaire are items eliciting information from teachers pertaining to their personal (gender), environmental (the geographical area where they grew up), educational (the graduation programs, branches/subjects, the experiences related to diversity/multicultural education), and professional (the number of cities they have worked, the province/ city they teach currently) characteristics (Table 1.) We also intended to obtain information from teachers about their ethnic, religious and linguistic (i.e. mother tongue) background. But we could not obtain official permission from authorities (Ministry of National Education) in Turkey.

\section{Culturally Relevant Education Self-Efficacy Scale (CRESES)}

For developing the scale, first, we searched an extensive literature review of CRE. Then, we followed Bandura's $(1977,2006)$ theoretical guidelines to construct self-efficacy scales. We found out several characteristics that instance the practices of CRE. Discovering these characteristics of CRE allowed us to write self-efficacy items that were coherent with the competencies. After creating items, we decided how to measure teachers' culturally relevant education self-efficacy perceptions, acknowledging the latest examinations about the best way to determine self-efficacy perceptions (Bandura, 2006; Pajares, Hartley, \& Valiante, 2001).

We discovered that Pajares et al. (2001) showed that writing a self-efficacy scale with a 0 to 100 response format was psychometrically stronger than a traditional 1-6 point Likert-type scale. We decided, therefore, to use the 0 to 100 rating scale. In the second phase, we administered the first draft of the CRESE Scale to a sample (N=395) of in-service teachers. This pilot data collection from the small-sample assisted us in fine-tuning the scale for large-scale data collection. The pilot study provided us with an opportunity to obtain precious data from teachers who then assisted in improving questions and response format and reducing redundant items.

The scale consists of 21 Likert-type items in which participants are asked to rate how confident they are in their ability to engage in specific CRE practices (e.g., "I am able to carry out studies that enable students to learn different cultural values") by 
indicating a degree of confidence ranging from 0 (no confidence at all) to 100 (completely confident). Participants' responses to each of the 21 items are calculated to generate a total score. Total scores can range from 0 to 2100. Participants who have higher scores on the scale are more confident in their ability, compared to those who were less confident in their abilities. Besides, the total score was divided by the total number of items to generate a CRESE strength index. This index, which may range from 0 to 100 , is a quantitative indicator of the strength of each teacher's CRESE perceptions. A copy of the scale is located in the appendix both in English and in Turkish.

\section{Data Analysis}

For analyzing the data, we conducted a preliminary analysis to assess the suitability of the data for factor analysis. Then, we conducted a principal axis analysis. Later, we conducted a descriptive analysis of the items on the CRESE Scale. Finally, we used the non-parametric Kruskal Wallis-H test and Mann Whitney-U test for comparisons of teachers' self-efficacy.

\section{Results}

\section{Factor Structure of the CRESE Scale}

To determine the suitability of the data for factor analysis, we examined KaiserMeyer-Olkin (KMO) measure of sampling adequacy (Kaiser, 1974), Bartlett's test of sphericity (1954), and the correlation matrix. We eliminated items which correlations coefficients less than .45. Also, KMO was .96, and Barletts's value [X2=6609.225; $s d=210, p<.001]$ was significant. Each of these analyses presented that factor analysis can be done with the obtained data (Tabachnick \& Fidell, 2001).

The principal axis factor analysis revealed the presence of three components with eigenvalues exceeding 1 , explaining $54.70 \%, 4.45 \%$, and $3.65 \%$ of the variance, respectively. An inspection of the scree-plot revealed a clear break after the first component. Also, by using Horn's Parallel Analysis Method and Exploratory Factor Analysis for determining the number of factors (Cokluk \& Kocak, 2016), we concluded that the CRESE Scale consisted of one factor and that the scale consisting of 21 items.

Total variance explained by the items was $54,166 \%$, which is somewhat higher than the $53 \%$ average of factor analysis studies (Henson \& Roberts, 2001, 2006). The one-factor solution explained approximately $54.166 \%$ of the variance, with factor loadings ranging from .61 to .78 . Factor loadings ranged from .61 for the ability to "communicate with all parents who have different cultural values" to .78 for the ability to "take into account culturally different students' interests when designing instructional processes" (see Table 2). Internal reliability for scores on the 21-item scale was .95, as estimated by Cronbach's alpha.

\section{Descriptive Analysis (Teachers' Perceptions)}

Teachers' culturally relevant education self-efficacy perceptions were highest for the ability to: "work with students who have different cultural values without being influenced by my own beliefs, opinions, and values." (M=86.6, SD=9.77) and "contribute 
to the peace of mind with their identity - their own differences." $(M=85.8, S D=10.76)$. Item-specific means were lowest among the teachers for the ability to: "develop various assessment tools that determine how culturally different students learn." (M=75.6, $\mathrm{SD}=9.89$ ), "design the classroom environments to reflect the different cultural values of all students." $(\mathrm{M}=77.4, \mathrm{SD}=14.89)$, and "revise teaching materials by refining them eliminating prejudiced thoughts to better reflect the cultural values of the students" $(\mathrm{M}=77.6, \mathrm{SD}=11.85)$. Teachers' total scores on the CRESE Scale ranged from 1060 to 2080. Participants in this study had a mean score of 1705.2 ( $S D=356.41)$. High scores on the CRESE scale indicate a greater sense of efficacy for engaging in specific instructional and non-instructional tasks associated with culturally relevant education. The descriptive statistics and factor loadings for the scale are presented in Table 2.

Table 2

Means, Standard Deviations, and Factor Loadings for Items on the CRESE Scale

\begin{tabular}{|c|c|c|c|c|}
\hline & $\begin{array}{l}\text { Items } \\
\text { (I am able to...) }\end{array}$ & M & SD & $\begin{array}{l}\text { Factor } \\
\text { loading }\end{array}$ \\
\hline (1) & $\begin{array}{l}\text { contribute to the peace of mind with their identity-their own } \\
\text { differences. }\end{array}$ & 85.8 & 10.76 & .73 \\
\hline (2) & $\begin{array}{l}\text { carry out studies that enable students to learn different cultural } \\
\text { values. }\end{array}$ & 80.6 & 18.87 & .76 \\
\hline (3) & $\begin{array}{l}\text { encourage students to give examples of their own culture in } \\
\text { the classroom. }\end{array}$ & 84.8 & 11.78 & .74 \\
\hline$(4)$ & $\begin{array}{l}\text { contribute to students to improve their critical perspectives } \\
\text { regarding prejudice towards different cultural values. }\end{array}$ & 83.6 & 16.78 & .76 \\
\hline$(5)$ & improve culturally different students' self-confidence. & 84.6 & 15.74 & .78 \\
\hline (6) & $\begin{array}{l}\text { link between previous knowledge (based on cultural values of } \\
\text { the students) and new knowledge. }\end{array}$ & 82.6 & 14.78 & .78 \\
\hline (7) & $\begin{array}{l}\text { take into account culturally different students' interests when } \\
\text { designing instructional processes. }\end{array}$ & 84.8 & 12.79 & .78 \\
\hline (8) & $\begin{array}{l}\text { work with students who have different cultural values without } \\
\text { being influenced by my own beliefs, opinions, and values. }\end{array}$ & 86.6 & 9.77 & .68 \\
\hline (9) & $\begin{array}{l}\text { solve the problems that may arise if some educational practices } \\
\text { conflict with different cultural values of the students. }\end{array}$ & 81.4 & 16.79 & .75 \\
\hline$(10)$ & $\begin{array}{l}\text { train students to examine the "inequalities" that exist in society } \\
\text { from a critical point of view. }\end{array}$ & 82.6 & 17.80 & .74 \\
\hline$(11)$ & increase culturally different parental involvement at schools. & 79.2 & 7.84 & .69 \\
\hline (12) & $\begin{array}{l}\text { plan the parents' meetings so that the parents do not feel } \\
\text { "other" themselves. }\end{array}$ & 82.8 & 15.79 & .72 \\
\hline$(13)$ & $\begin{array}{l}\text { enhance all of the students higher-order skills, despite their } \\
\text { own disadvantages and differences. }\end{array}$ & 78.4 & 9.85 & .66 \\
\hline$(14)$ & $\begin{array}{l}\text { manage a culturally diverse classroom (for example, linguis- } \\
\text { tically diverse). }\end{array}$ & 78.6 & 6.93 & .69 \\
\hline$(15)$ & $\begin{array}{l}\text { organize collaborative learning environments among culturally } \\
\text { diverse students. }\end{array}$ & 81.8 & 13.77 & .76 \\
\hline$(16)$ & communicate with all parents who have different cultural values. & 82.0 & 15.81 & .61 \\
\hline$(17)$ & $\begin{array}{l}\text { conduct assessment-evaluation activities taking into account } \\
\text { the different cultural values of the students. }\end{array}$ & 78.4 & 6.88 & .67 \\
\hline
\end{tabular}


Continuation of Table 2

(18) revise teaching materials by refining them from prejudiced thoughts to better reflect the cultural values of the students.

$\begin{array}{lll}77.6 & 11.85 \quad .76\end{array}$

(19) develop teaching materials for introducing to students the country's (Turkey's) cultural diversity.

$\begin{array}{lll}78.0 & 14.83 \quad .73\end{array}$

(20) design the classroom environments to reflect the different cultural values of all students.

$\begin{array}{lll}77.4 & 14.89 & .75\end{array}$

(21) develop various assessment tools that will determine how culturally different students learn.

$\begin{array}{lll}75.6 & 9.89 \quad .72\end{array}$

\section{Comparison Teachers' Self-Efficacy Perceptions According to Some Variables}

The findings of whether the teachers' self-efficacy perceptions differ significantly according to some variables are as follows (See Table 3 and 4):

Table 3

Comparison of Teachers' Self-Efficacy Perceptions According to Graduation, Teaching Subjects, the City they Serve in Currently and the Geographical Region they Mostly Lived in

\begin{tabular}{|c|c|c|c|c|c|c|c|}
\hline & $\mathrm{N}$ & $\mathrm{X}$ & $\begin{array}{l}\text { Sequence } \\
\text { average }\end{array}$ & sd & $\mathrm{x}^{2}$ & $\mathrm{p}$ & $\begin{array}{l}\text { Significant } \\
\text { difference }\end{array}$ \\
\hline \multicolumn{8}{|l|}{ Graduation } \\
\hline 1. Teachers' Training School & 44 & 4,16 & 717,42 & \multirow{6}{*}{5} & \multirow{6}{*}{16,80} & \multirow{6}{*}{, $005 *$} & $1>4$ \\
\hline 2. Undergraduate-College & 120 & 4,02 & 632,71 & & & & $2>4$ \\
\hline 3. Faculty of Education & 755 & 4,10 & 676,55 & & & & $3>4$ \\
\hline 4. Vocational-Technical Education & 87 & 3,80 & 505,30 & & & & $3>5$ \\
\hline 5. Faculty of Arts and Science & 296 & 4,00 & 613,60 & & & & $5>4$ \\
\hline \multicolumn{5}{|l|}{ Teaching subjects } & & & \\
\hline 1. Basic Education & 210 & 4,08 & 665,68 & \multirow{7}{*}{6} & \multirow{7}{*}{21,99} & \multirow{7}{*}{, $001 *$} & $1>4$ \\
\hline 2. Social Sciences & 331 & 4,12 & 689,06 & & & & $6>1$ \\
\hline 3. Foreign Language & 139 & 4,01 & 618,72 & & & & $2>4$ \\
\hline 4. Sciences & 271 & 3,96 & 588,33 & & & & $6>3$ \\
\hline 5. Vocational Courses & 169 & 4,03 & 633,58 & & & & $6>7$ \\
\hline $\begin{array}{l}\text { 6. Psychological Counseling and } \\
\text { Guidance }\end{array}$ & 79 & 4,26 & 779,94 & & & & $6>4$ \\
\hline 7. Mathematics & 103 & 4,03 & 643,21 & & & & $6>5$ \\
\hline \multicolumn{8}{|l|}{ The city they work in currently } \\
\hline 1. Van & 344 & 4,35 & 853,91 & \multirow{7}{*}{6} & \multirow{7}{*}{340,76} & \multirow{7}{*}{, $000 *$} & $1>3 ; 2>5$ \\
\hline 2. Diyarbakir & 210 & 4,45 & 892,77 & & & & $1>4 ; 2>6$ \\
\hline 3. Antalya & 154 & 3,70 & 474,11 & & & & $1>5 ; 2>7$ \\
\hline 4. Konya & 144 & 3,77 & 463,05 & & & & $1>6 ; 7>3$ \\
\hline 5. Trabzon & 159 & 3,80 & 460,89 & & & & $1>7 ; 7>4$ \\
\hline 6. Izmir & 159 & 3,81 & 459,44 & & & & $2>3 ; 7>5$ \\
\hline 7. Istanbul & 132 & 4,01 & 613,66 & & & & $2>4 ; 7>6$ \\
\hline
\end{tabular}


Continuation of Table 1

The Geographical Regions

\begin{tabular}{|c|c|c|c|c|c|c|c|}
\hline 1. The Eastern Anatolia & 318 & 4,25 & 795,14 & \multirow{7}{*}{6} & \multirow{7}{*}{\multicolumn{2}{|c|}{186,3}} & $1>3 ; 2>1$ \\
\hline 2. The Southeastern Anatolia & 153 & 4,48 & 909,48 & & & & $2>5 ; 2>3$ \\
\hline 3. The Mediterranean & 165 & 3,88 & 558,32 & & & & $1>4 ; 2>4$ \\
\hline 4. The Central Anatolia & 171 & 3,91 & 554,94 & & & & $1>5 ; 2>7$ \\
\hline 5. The Black Sea & 166 & 3,85 & 506,20 & & & & $7>5 ; 1>7$ \\
\hline 6. The Aegean & 188 & 3,89 & 530,70 & & & & \\
\hline 7. The Marmara & 141 & 4,00 & 605,90 & & & & \\
\hline
\end{tabular}

Table 4

Comparison of Teachers' Self-Efficacy Perceptions According to the Number of Cities they Worked, Experiences Related to Multicultural Education and Gender

\begin{tabular}{|c|c|c|c|c|c|c|}
\hline & $\mathrm{N}$ & $\mathrm{X}$ & $\begin{array}{l}\text { Sequence } \\
\text { number }\end{array}$ & $\begin{array}{l}\text { Sequence } \\
\text { total }\end{array}$ & U value & $\mathrm{p}$ \\
\hline \multicolumn{7}{|c|}{ The number of cities } \\
\hline One city & 782 & 4,08 & 668,17 & 522505,50 & \multirow{2}{*}{190287,500} & \multirow{2}{*}{, $049 *$} \\
\hline At least two cities & 520 & 4,02 & 626,44 & 325747,50 & & \\
\hline \multicolumn{7}{|c|}{ Experiences related to multicultural education } \\
\hline Yes & 626 & 4,17 & 726,35 & 454695,00 & \multirow{2}{*}{164732,000} & \multirow{2}{*}{, $000 *$} \\
\hline No & 676 & 3,95 & 582,19 & 393558,00 & & \\
\hline \multicolumn{7}{|l|}{ Gender } \\
\hline Male & 715 & 4,11 & 687,99 & 491913,50 & \multirow{2}{*}{183761,500} & \multirow{2}{*}{, $000 *$} \\
\hline Female & 587 & 3,99 & 607,05 & 356339,50 & & \\
\hline
\end{tabular}

We used the Kruskal Wallis-H Test to determine whether there is a significant difference among the self-efficacy perceptions of the teachers according to the valuables. We also used the Mann Whitney-U test to find out the source of difference, for binary comparisons.

According to the graduate program, we found a significant difference $\left(X^{2}=16,80\right.$ and $\mathrm{p}<.05)$. The comparisons, also, showed that there was a significant difference among those of the other four graduates programs and those of Vocational-Technical Education Graduates, and the differences were in favor of the other four; between those of Faculty of Education Graduates and those of Faculty of Arts and Science Graduates, and the difference was in favor of the Faculty of Education Graduates.

According to the teaching subjects, we found a significant difference $\left(X^{2}=21,99\right.$ and $\mathrm{p}<.05$. The comparisons showed that PCG teachers had significantly higher selfefficacy perceptions than basic education, foreign language, sciences, vocational courses, and mathematics teachers. Similarly, basic education and social sciences teachers had higher self-efficacy perceptions than sciences teachers.

According to the city they serve in currently, we found a significant difference $\left(\mathrm{X}^{2}=340,76\right.$ and $\left.\mathrm{p}<.05\right)$ and the comparisons showed that the teachers who work in the Van or Diyarbakir had significantly higher self-efficacy perceptions than the teachers who work in the Antalya, Konya, Izmir, Istanbul, and Trabzon. Similarly, the teachers who work in Istanbul had significantly higher self-efficacy perceptions than the teachers who work in the Antalya, Konya, Izmir, and Trabzon. 
According to the geographical regions they mostly lived in, we found a significant difference $\left(\mathrm{X}^{2}=186,3\right.$ and $\left.\mathrm{p}<.05\right)$. The comparisons showed that the teachers mostly living in the Eastern Anatolia had significantly higher self-efficacy perceptions than the teachers mostly living in the Mediterranean, Central Anatolia, Black Sea, and the Marmara. Similarly, the teachers mostly living in the Southeastern Anatolia had significantly higher self-efficacy perceptions than the teachers mostly living in the Black Sea, Marmara, Eastern Anatolia, Mediterranean, and the Central Anatolia. Also, there was a significant difference between those mostly living in the Marmara and those mostly living in the Black sea, and the difference was in favor of those mostly living in the Marmara.

The average of the teachers who have worked in one city was higher than the teachers have worked in at least two cities. The average of the teachers who had experiences related to multicultural education (teachers who have been involved in any seminar or courses, have read book-articles or have any experience regarding multiculturalism or cultural differences) was higher than the teachers who had no experience and the average of the male teachers was higher than the female teachers. Also, we found significant differences $(\mathrm{p}<.05)$. The significant differences were in favor of teachers who have worked in one city so far, in favor of teachers who had experiences related to multicultural education and in favor of male teachers, respectively.

\section{Discussion}

We designed this study to examine teachers' culturally relevant education selfefficacy perceptions in Turkey. However, there were very limited studies on CRE. Also, there were no instruments that can measure teachers' culturally relevant education selfefficacy perceptions in Turkey. Hence, we developed a scale and administered this scale to teachers. In the next section, we discussed findings using three sub-topics: Culturally Relevant Education Self-Efficacy Scale, Teachers' CRESE Perceptions and The Comparison of Teachers' Self-efficacy Perceptions According to Some Variables.

\section{Culturally Relevant Education Self-Efficacy Scale}

To accomplish the aims of the study, first, we followed Bandura's (2006) guidelines to develop self-efficacy scales. Second, we searched a literature review that enabled us to identify some fundamental CRE competencies that were used to develop items for the scale. The results suggest that the measure consists of a single factor. Teachers' scores on the CRESE Scale were highly reliable. The scale explained $54.166 \%$ amount of variance and amount of variance explained by the scale showed higher factorial validity than studies published in some previous works (Siwatu, 2007). However, there were three important limitations. First, evidence of construct validity was not obtained. Because there were no scales about CRE in Turkey or within the Turkish language, we could not match or correlate scores on the CRESE Scale with other scales. Second, we could not know whether the sample contains participants from diverse backgrounds including ethnicity, mother language, and religion. Finally, confirmatory factor analysis was not conducted. In spite of these limitations, we believe that the development of the CRESE Scale will make positive contributions to the research on teacher CRE' self-efficacy and CRE, in Turkey. 


\section{Teachers' CRESE Perceptions}

The findings from the descriptive analysis suggest that teachers were less efficacious in their ability to revise the teaching-learning materials (books, journals) in terms of cultural diversity; to give relevant examples to better reflect the cultural values of the students; to improve the measurement instruments that determine the learning levels of the culturally different students; to reflect the different cultural values of all the students in the classroom; to increase in school parents and families' participation regardless of their culture; and to develop teaching materials to make students recognize different cultures, - than they are in their ability to encourage students to give examples of their own culture in the classroom. The findings of the studies by Siwatu (2007) and Siwatu, Polydore and Starker (2009) match up with the findings from this study. In the relevant studies, it was concluded that teachers have a lower self-efficacy perception similar to the results of this study in terms of conducting teaching activities according to culturally different students, and in developing cooperation by providing effective communication and family involvement.

In this study, the reasons why teachers have lower self-efficacy perceptions include the fact that teachers do not know different languages, cannot communicate with different language-speaking parents (usually they use another teacher who speaks the language as a translator) and they fail to provide them with access to the school. On the other hand, it may be difficult for teachers to try to consider different cultural values in this process, especially when there is the need for a high level of pedagogical competence in the regulation of assessment and evaluation processes. Another possibility might be that formal, compulsory curricula and regulations may be the reason for teachers' lower self-efficacy perceptions compared to other situations in revising programs and materials. These results are similar to those of Ladson-Billings' (1992, 1995a) studies. Also, culturally irrelevant teacher training programs could affect teachers' perceptions. Kotluk (2018) stated that teachers feel inadequate when they encounter CLD students in their classes. Teachers correlated the reason of this adequacy with the teacher training program.

The findings revealed that teachers in Turkey have high levels of CRE self-efficacy perception. According to social cognitive theory, a teacher's perceived self-efficacy perception estimates whether s/he behaves in ways to make things happen (Bandura, 1977). It is also believed that the teachers with a high level of CRE self-efficacy perception can design and implement teaching processes effectively for the CLD students and that teachers with a high level of self-efficacy perceptions are more likely to consider students' different cultural values in teaching processes than teachers with low self-efficacy perceptions (Siwatu, 2007, 2008, 2011; Siwatu, Chesnut, Alejandro, \& Young, 2016). Thus, the results obtained from this study, when the cultural diversity of Turkey is considered, can be seen as positive in terms of the culturally different students' educational processes. However, it is important to note that teachers' high self-efficacy perceptions will not automatically result in implementing the practices of CRE into the classroom.

\section{The Comparison of Teachers' Self-Efficacy Perceptions According to Some Variables}

Another question of this research was whether the teachers' CRE self-efficacy perceptions differ significantly according to some variables. In the following section, the results of the analysis are presented. 


\section{The number of cities they have worked in so far}

The results show that teachers who have worked in one city had statistically significant higher self-efficacy perception than teachers who have worked in two cities so far. Normally, teachers' experience of working in different cities and having culturally different students are expected to have a positive influence on their own self-efficacy perceptions and it appears that studies are indicating this effect (Evans, 2017). However, the results obtained in this study do not match this situation. The reason for this outcome may be the effect of the teachers' first-hand negative experiences (Arseven, 2016). The fact that the teachers who have worked in two different cities had a lot of difficulties in the context of cultural differences in the schools might have affected their self-efficacy perceptions negatively when compared to those who have worked in one city so far.

\section{Experiences related to multicultural education}

The research revealed that the teachers' self-efficacy perceptions differ statistically according to their experiences related to multiculturalism: such as participating in any seminar, taking courses, reading books and articles about multiculturalism or cultural differences. The difference was in favor of the teachers who had experience. Consequently, it can be said that taking courses and reading books about cultural diversity affect selfefficacy perceptions positively. Indeed, Frye, Button, Kelly, and Button (2010) have concluded that cultural diversity-related training courses positively affect teacher candidates' perceptions and their attitudes towards instruction for culturally diverse students. Similarly, Evans (2017) noted that teachers had a positive and significant influence on their self-efficacy beliefs when they were taking lectures or courses related to cultural differences during or after undergraduate education.

\section{The graduation}

In the study, we found that the teachers' self-efficacy perceptions differ statistically according to their graduation programs (faculty). The difference was in favor of the teachers who graduated from the faculty of education. Also, the teachers with the lowest self-efficacy perception of CRE are those who graduated from vocational-technical education faculty, and science and art faculty. These results may be related to the likelihood that the individual differences of the students are more likely to be taken into account in the teacher education courses and the education programs of the education faculties. The graduates of program types, whose primary mission is to train teachers, are more responsive and more alert to differences than those who graduated from other programs.

\section{Teaching subjects}

In the study, we revealed that the teachers' self-efficacy perceptions differ statistically according to their teaching subjects or fields. The difference was in favor of the teachers whose teaching subjects were PCG and social sciences. In contrast, the teachers with the lowest self-efficacy perceptions were science teachers. The low self-efficacy perceptions of science teachers may arise from the fact that teachers thought that science and culture are different things from each other. Brown (2017), similarly, emphasizes that there is a misconception among teachers that CRE is not suitable for science and mathematics. According to Gay (2002), this view stems from the fact that many teachers are not well informed about different cultural groups and that they are separated from multicultural education. 
The city they work in currently and the geographical regions they mostly lived in

The findings of this study suggested that the teachers' self-efficacy perceptions differ statistically according to the city in which they are working. The difference was in favor of teachers working in Diyarbakir and Van. Also, the teachers with the lowest self-efficacy perception of CRE are the teachers in Izmir, Trabzon, and Konya respectively. Similarly, we found that teachers' self-efficacy perceptions were statistically differentiated by the variables of the geographical area where the teachers live most of their lives. This difference was in favor of the teachers who have lived mostly in Southeast, Eastern Anatolia and the Marmara region. In addition, the teachers with the lowest self-efficacy perception of CRE are the teachers who have spent most of their lives in the Black Sea, Aegean and Central Anatolia regions, respectively. The factors that may have influenced teachers' self-efficacy perceptions can be that:

First, in Turkey, it is a known fact that almost all teachers want to work in their home towns because of the social, cultural and economic conditions, so they want to be appointed to the closest city. The fact that many teachers are working with students from their own culture and the familiarity of these cultures may lead to a higher perception of self-efficacy. In Kotluk's (2018) doctoral dissertation, several teachers in the face-toface interviews expressed their reasons for the high perception of self-efficacy as:

It is very advantageous for me in the first grade because I know the culturally different students' language (Kurdish) and, I can communicate with them and their families easily (p. 154)

My whole life passed in Istanbul. Would not it have been difficult if I had been appointed to Kars? I think I would be (p. 156)

Second, in some regions and cities, the number of CLD students is higher than in other regions and cities. Consequently, the teachers who have lived or worked and served in these regions frequently encounter CLD students. They may develop strategies to cope with the challenges they face, so their self-efficacy beliefs may have increased. Kotluk (2018) indicates that when compared with other cities, teachers especially the first-year teachers who work in Van, face more difficulties in teaching Turkish due to students' different mother tongue. Similarly, the results obtained according to the geographical region variables in this study overlap with the results of the study conducted by Polat and Kilic (2013). The authors pointed out that teachers from Southeast Anatolia had a higher perception of multicultural competence than teachers from other regions; while teachers from the Aegean Region had a lower perception of competence than those from Marmara Region. Kilic and Polat (2013) explained these findings connected to the cultural diversity of Marmara and Southeastern Anatolian Regions.

\section{Gender}

The results suggest that teachers' self-efficacy perceptions differ statistically according to gender. This significant difference was in favor of male teachers. This result shows that female teachers had lower self-efficacy perceptions than male teachers. In view of the information derived from Kotluk's (2018) study on the causes of this situation: female teachers have to struggle with gender discrimination in society, while struggling with the difficulties stemming from cultural differences. They are also being exposed to gender-based, prejudiced, marginalizing attitudes of parents and students including being 
biased towards the role of women in the books or materials used. Hence, all these can be said to have negative effects on female teachers' self-efficacy perceptions.

\section{Implications}

We believe that the CRESE Scale is a measure that can be used for multiple purposes in Turkey, especially in teacher education. Because there is a great need for the culturally relevant teacher training programs in Turkey regarding Turkey's cultural diversity and teachers' assign system (Aydin \& Kaya, 2017, 2019; Aydin, Gundogdu, \& Akgul, 2019; Kotluk \& Kocakaya, 2018a, 2018b, 2019). We would like to highlight two implications:

First, we think that the CRESE Scale will be a useful instrument for teacher educators who are interested in determining pre-service teachers' CRESE perceptions. Determining pre-service teachers' self-efficacy means that teacher educators can design better culturally relevant education courses for them in Turkey's universities. As Stites, Rakes, Noggle, and Shah (2018) suggested, preparation programs need to provide a more coherent conceptual framework to guide the enhancement of both course and field work related to inclusive and effective inclusive practices.

We want to note that after administering the Scale, it can be useful to explore preservice teachers' self-efficacy doubts qualitatively. Both the quantitative and qualitative data, then, can be used to design a teacher education course. Consequently, action studies similar to the one conducted by Tuncel (2017), should be designed for the preservice teachers in Turkey, and further studies might be carried out to determine how these programs affect their teaching process, planning, application, and evaluation skills. As Turkey hosts many CLD students, it is highly possible for these pre-service teachers to serve in CLD classrooms in the future, and to design such courses can increase future teachers' knowledge, skills, attitudes, disposition, and self-efficacy perceptions of CRE.

Second, Turkey is the largest country that receives Syrian refugees in the world and nearly 1.5 million of them are at school-age according to the Republic of Turkey Ministry of Interior Directorate-General for Migration Management, 2018, and to The United Nations Human Rights Council, 2018. Aras and Yasun (2016) estimated that about $65 \%$ of Syrians will remain in Turkey even after the war concludes. As a result of this possibility, teachers may teach Syrian students in their classrooms from pre-schools to high schools, in Turkey. It is quite critical to manage the integration of such a large number of CLD students into the educational system of Turkey for planning of Turkey's future. In this context, researchers highlight that multicultural education (Aydin, 2013; Gunay \& Aydin, 2015; Tezel-McCarthy, 2018) or culturally relevant education needs to be integrated into the national curriculum as an expanded alternative approach (Kotluk, 2018; Kotluk \& Kocakaya, 2018a, 2018b).

However, Turkey has not still designed any program, including teachers training programs, to educate and integrate of CLD students, including ethnic minorities, migrants or refugees (Aydin \& Kaya, 2019; Icduygu, 2015; Kotluk \& Kocakaya, 2018a). However, several relevant studies indicated that both Syrian students and other CLD students often experience such problems as exclusion, loneliness, prejudices, discrimination, academic failures in Turkish public schools (Kotluk, 2018; Kotluk \& Kocakaya, 2018b). This means that teachers' skills in teaching CLD students in Turkey remains one of the important problems (Alpaydin, 2017). In Kotluk's (2018) doctoral dissertation, he revealed that teachers had challenges that related to culturally different parents and students, and teaching CLD students. Interviewed teachers, in Kotluk's study, indicated that they 
had difficulties, particularly in: achieving parental involvement, in giving relevant examples to the CLD students, in developing responsive materials, in connecting subject content with their daily lives, in managing classroom where CLD students are together, in teaching, reading and writing to non-Turkish learners, and in revising programs and materials.

In the light of those precious articles' and thesis' findings, as researchers of this study, we strongly suggest that the CRESE Scale can be administered to in-service teachers, who serve in such cities as Hatay, Gaziantep, and Kilis because the number of Syrian students in those cities is higher than in other cities. Also, the scale can be administered to in-service teachers who serve in other cities, in which Turkey's cultural diversity is more visible. After determining teachers' existing CRESE perceptions, creating an intervention designed to increase the strength of in-service teachers' perceptions can be effective. There are already studies, in the literature indicating that culturally relevant, responsive and sustaining intervention or enhanced programs are developed for teachers, or prospective teachers' perceptions about CRE (Evans, 2017; Ritosa, 2017; Williams, Edwards, Kuhel, \& Lim, 2016).

\section{Conclusions}

In this study, by following Bandura's (2006) guidelines for developing a self-efficacy scale, we developed the CRESE Scale for determining teachers' self-efficacy perceptions in Turkey. Since there were not existing scales before, we are hopeful about the utilisation of the CRESE Scale in Turkey. However, additional research is needed to examine the psychometric properties of the scale. We believe that the CRESE scale can be a useful instrument for determining both pre-service and in-service teachers' CRESE perceptions, in Turkey. Both teachers' scores on the CRESE Scale can be used to inform the creation of intervention programs focused on developing their CRE knowledge, skills, attitudes, and self-efficacy perceptions. However, in future studies, such measures as "observation form for self-assessment" and "culturally relevant classroom management skills" can be used to improve skills profiles for culturally relevant teachers.

We also revealed that the teachers in Turkey have high levels of CRE self-efficacy perception. But, it is quite crucial to determine whether teachers' high self-efficacy perceptions automatically result in implementing the practices of CRE within the classroom or not. It would therefore be useful to carry out a new study, by observing teachers, for this purpose. In addition, the teachers in this study were in-serviced and had experiences with CLD students. Hence, a potential mixed-method study may prove to be beneficial in examining the similarities and differences between pre- and in-service teachers with different CRESE perceptions. There is also a need for research projects that focus on the differences between teachers who are in the first year of teaching and the more experienced teachers. In particular, it is also possible to make comparisons between teachers who have not worked outside their own culture and those who have already done so.

We found out that teachers' self-efficacy perceptions differ significantly: according to the program from which they graduated, the number of cities they have worked in so far, their teaching subjects, experience-related multicultural education, the cities they work in currently, the geographical regions they mostly live in and their gender. This means that some academic and demographic characteristics of teachers influence their perceptions. Additional research, especially qualitative studies, is needed to examine the reasons for these statistical differences. By determining teachers' opinions and beliefs 
for CRE in advance, how these opinions and beliefs are reflected in the classroom setting, teaching activities, classroom management and teacher-student relationships can be observed.

\section{Appendix}

\section{Culturally Relevant Education Self-Efficacy Scale (in English)}

Directions: Rate how confident you are in your ability to successfully accomplish each of the tasks listed below. Each task is related to culturally relevant education. Please rate your degree of confidence by recording a number from 0 (no confidence at all) to 100 (completely confident). Remember that you may use any number between 0 and 100 .

\begin{tabular}{|c|c|c|c|c|c|c|c|c|c|}
\hline 10 & 20 & 30 & 40 & 50 & 60 & 70 & 80 & 90 & 100 \\
\hline $\begin{array}{l}\text { No } \\
\text { confidence } \\
\text { at all }\end{array}$ & \multicolumn{7}{|c|}{$\begin{array}{c}\text { Moderately } \\
\text { confident }\end{array}$} & \multicolumn{2}{|c|}{$\begin{array}{r}\text { Completely } \\
\text { confident }\end{array}$} \\
\hline
\end{tabular}

I am able to:

(1) contribute to the peace of mind with students' identity-their own differences.

(2) carry out studies that enable students to learn different cultural values.

(3) encourage students to give examples of their own culture in the classroom.

(4) contribute to students to improve their critical perspectives regarding prejudice towards different cultural values.

(5) improve culturally different students' self-confidence

(6) link between previous knowledge (based on cultural values of the students) and new knowledge.

(7) take into account culturally different students' interests when designing instructional processes.

(8) work with students who have different cultural values without being influenced by my own beliefs, opinions, and values.

(9) solve the problems that may arise if some educational practices conflict with different cultural values of the students.

(10) train students to examine the "inequalities" that exist in society from a critical point of view.

(11) increase culturally different parental involvement at schools.

(12) plan the parents' meetings so that the parents do not feel "other" themselves.

(13) enhance all of the students higher-order skills, despite their own disadvantages and differences

(14) manage a culturally diverse classroom, (for example, linguistically diverse)

(15) organize collaborative learning environments among culturally diverse students.

(16) communicate with all parents who have different cultural values.

(17) conduct assessment-evaluation activities taking into account the different cultural values of the students.

(18) revise teaching materials by defining them free of prejudiced thoughts to better reflect the cultural values of the students

(19) develop teaching materials for introducing to students the country's (Turkey's) cultural diversity. 
(20) design the classroom environments to reflect the different cultural values of all students.

(21) develop various assessment tools that will determine how culturally different students learn.

Author's note:

This article is derived from Nihat Kotluk's Ph.D. dissertation entitled "Examining teachers' views and self-efficacy perceptions about culturally relevant/responsive education (in Turkey)".

\section{References}

Alpaydin, Y. (2017). An analysis of educational policies for school-aged Syrian refugees in Turkey. Journal of Education and Training Studies, 5(9), 36-44. doi: 10.11114/ jets.v5i9.2476

Aras, B., \& Yasun, S. (2016). The educational opportunities and challenges of Syrian refugee students in Turkey: Temporary education centers and beyond. IPC-Mercator policy brief. Retrieved from http://ipc.sabanciuniv.edu/publication/the-educationalopportunities-and-challanges-of-syrian-refugee-students-in-turkey-temporaryeducation-centers-and-beyond/?lang=en

Aronson, B., \& Laughter, J. (2016). The theory and practice of culturally relevant education: A synthesis of research across content areas. Review of Educational Research, 86(1), 163-206. Retrieved from https://doi.org/10.3102/00346543155 82066

Arseven, A. (2016). Self-efficacy: A concept analysis. Turkish Studies-International Periodical for the Languages, Literature and History of Turkish or Turkic, 11(19), 6380. Retrieved from http://turkishstudies.net/files/145030429_6ArsevenAyla-egt-6380.pdf

Aydin, H. (2013). Dunya'da ve Turkiye'de cokkulturlu egitim tartismalari ve uygulamalari [Discussion and application of multicultural education in Turkey and the World]. Ankara: Nobel Akademik Yayincilik.

Aydin, H., Gundogdu, M., \& Akgul, A. (2019). Integration of Syrian refugees in Turkey: Understanding the educators' perception. Journal of International Migration \& Integration, 19(1), 1-12. doi: 10.1007/s12134-018-0638-1

Aydin, H., \& Kaya, Y. (2019). Education for Syrian refugees: The new global issue facing teachers and principals in Turkey. Educational Studies, 55(1), 46-71. doi: 10.1080/00131946.2018.1561454

Aydin, H., \& Kaya, Y. (2017). Educational needs and barriers for Syrian refugee students in Turkey: A qualitative case study. Intercultural Education, 28(5), 456-473. doi: 10.1080/14675986.2017.1336373

Bandura, A. (1977). Self-efficacy: Toward a unifying theory of behavioral change. Psychological Review, 84(2), 191-215. Retrieved from http://dx.doi.org/10.1037/ 0033-295X.84.2.191

Bandura, A. (1997). Self-efficacy: The exercise of control. New York: W. H. Freeman and Company.

Bandura, A. (2006). Guide for creating self-efficacy scales. In Pajares, F., \& Urdan, T. (Eds.), Self-efficacy beliefs of adolescents (pp. 307-337). Greenwich, CT: Information Age. 
Barnes, C. J. (2006). Preparing pre-service teachers to teach in a culturally responsive way. Negro Educational Review, 57(1-2), 85-100. Retrieved from http://citeseerx. ist.psu.edu/viewdoc/download?doi=10.1.1.458.3111\&rep=rep1\&type=pdf

Brown, M. R. (2007). Educating all students: Creating culturally responsive teachers, classrooms, and schools. Intervention in School and Clinic, 43(1), 57-62. Retrieved from https://doi.org/10.1177\%2F10534512070430010801

Brown, J. C. (2017). A metasynthesis of the complementarity of culturally responsive and inquiry-based science education in K-12 settings: Implications for advancing equitable science teaching and learning. Journal of Research in Science Teaching, 54(9), 1143-1173. Retrieved from https://doi.org/10.1002/tea.21401

Cokluk, O., \& Kocak, D. (2016). Using Horn's parallel analysis method in exploratory factor analysis for determining the number of factors. Educational Sciences: Theory \& Practice, 16, 537-551. Retrieved from https://files.eric.ed.gov/fulltext/ EJ1101205.pdf

Durden, T., Dooley, C. M., \& Truscott, D. (2016). Race still matters: Preparing culturally relevant teachers. Race Ethnicity and Education, 19(5), 1003-1024. https://doi.org/ 10.1080/13613324.2014.969226

Ellerbrock, C. R., Cruz, B. C., Vásquez, A., \& Howes, E. V. (2016). Preparing culturally responsive teachers: Effective practices in teacher education. Action in Teacher Education, 38(3), 226-239. Retrieved from https://doi.org/10.1080/01626620. 2016.1194780

Evans, K. (2017). Examining the culturally responsive teaching self-efficacy of teacher candidates in Hawaii. Unpublished doctoral dissertation, Walden University. Retrieved from http://scholarworks.waldenu.edu/cgi/viewcontent.cgi ?article= 4448\&context $=$ dissertations

Frye, B., Button, L., Kelly, C., \& Button, G. (2010). Preservice teachers's self-perceptions and attitudes toward culturally responsive teaching. Journal of Praxis in Multicultural Education, 5(1), 6-22. Retrieved from https://digitalscholarship.unlv.edu/cgi/ viewcontent.cgi? article $=1029 \&$ context $=$ jpme

Gay, G. (2002). Preparing for culturally responsive teaching. Journal of Teacher Education, 53(2), 106-116. Retrieved from https://doi.org/10.1177\%2F002248710 2053002003

Gay, G. (2010). Acting on beliefs in teacher education for cultural diversity. Journal of Teacher Education, 61(1-2), 143-152. Retrieved from https://doi.org/10.1177/ 0022487109347320

Gay, G. (2013). Teaching to and through cultural diversity. Curriculum Inquiry, 43(1), 48-70. Retrieved from https://doi.org/10.1111/curi.12002

Gay, G. (2018). Culturally responsive teaching: Theory, research, and practice ( $\left.3^{\text {rd }} \mathrm{ed}.\right)$. New York and London: Teachers College Press.

Gunay, R., \& Aydin, H. (2015). The inclinations in studies on multicultural education in Turkey: A content analysis study (2005-2014). Education and Science, 40(178), 1-22. doi: 10.15390/EB.2015.3294

Henson, R. K., \& Roberts, J. K. (2001). Exploratory factor analysis reporting practices in published research. In Thompson, B. (Ed.), Advances in social science methodology, 6. Samford, CT: JAI Press. 
Henson, R. K., \& Roberts, J. K. (2006). Use of exploratory factor analysis in published research common errors and some comment on improved practice. Educational and Psychological Measurement, 66, 393-416. Retrieved from https://doi.org/ $10.1177 \% 2 \mathrm{~F} 0013164405282485$

Heasly, B., Lindner, J., Iliško, Dz., \& Salīte, I. (2019). Editorial. Discourse and Communication for Sustainable Education, 10(2), 1-4.

Heasly, B., Lindner, J., Iliško, Dz., \& Salìte, I. (2020). From initiatives, to insights, to implementation of the sustainability and securitability agenda for 2030. Discourse and Communication for Sustainable Education, 11(1), 1-4.

Icduygu, A. (2015). Syrian refugees in Turkey: The long road ahead. Washington, DC: Migration Policy Institute Press.

Kaiser, H. F. (1974). An index of factorial simplicity. Psychometrika, 39(1), 31-36. Retrieved from https://doi.org/10.1007/BF02291575

KONDA Research and Consultancy. (2006). Who we are? Social structure research. Retrieved from http://www.konda.com.tr/tr/raporlar/2006_09_KONDA_ Toplumsal_Yapi.pdf

Kotluk, N., \& Kocakaya, S. (2018a). Turkiye icin alternatif bir anlayis: Kulturel degerlere duyarli egitim [An alternative approach for Turkey: Culturally relevant/responsive education]. YYU Journal of Education, 15(1), 749-789. Retrieved from http://dx.doi.org/10.23891/efdyyu.2018.86

Kotluk, N., \& Kocakaya, S. (2018b). Culturally relevant/responsive education: What do teachers think in Turkey? Journal of Ethnic and Cultural Studies, 5(2), 98-117. Retrieved from http://www.ejecs.org/index.php/JECS/article/view/123/pdf

Kotluk, N. (2018). Kulturel degerlere duyarli egitime iliskin ogretmenlerin oz-yeterlik algilarinin ve goruslerinin incelenmesi [Examining teachers' views and self-efficacy perceptions about culturally relevant/responsive education (in Turkey)]. (Unpublished Doctoral dissertation). Yuzuncu Yil University, Van, Turkey. Retrieved from https://tez.yok.gov.tr/UlusalTezMerkezi/giris.jsp

Kotluk, N., \& Kocakaya, S. (2019). Teachers' views about culturally relevant education in Turkey: A mixed methods study. Sakarya University Journal of Education, 9(2), 304-334. Retrieved from https://doi.org/10.19126/suje.541535

Ladson-Billings, G. (1992). Reading between the lines and beyond the pages: A culturally relevant approach to literacy teaching. Theory into Practice, 31(4), 312-320. Retrieved from http://www.jstor.org/stable/1476313

Ladson-Billings, G. (1995a). But that's just good teaching! The case for culturally relevant pedagogy. Theory into Practice, 34(3), 159-165. Retrieved from https://doi.org/ 10.1080/00405849509543675

Ladson-Billings, G. (1995b). Toward a theory of culturally relevant pedagogy. American Educational Research Journal, 32(3), 465-491. Retrieved from https://doi.org/ $10.3102 \% 2 F 00028312032003465$

Ladson-Billings, G. (2014). Culturally relevant pedagogy 2.0: The remix. Harvard Educational Review, 84(1), 74-84. Retrieved from https://doi.org/10.17763/haer. 84.1.p2rj131485484751

Lambeth, D. T., \& Smith, A. M. (2016). Pre-service teachers' perceptions of culturally responsive teacher preparation. The Journal of Negro Education, 85(1), 46-58. doi: 10.7709/jnegroeducation.85.1.0046 
Nieto, S. (2000). Placing equity front and center: Some thoughts on transforming teacher education for a new century. Journal of Teacher Education, 51(3), 180-187. Retrieved from https://doi.org/10.1177/0022487100051003004

Pipere, A. (2019). Journal of Teacher Education for Sustainability after the UN Decade of Education for Sustainable Development: Exploring for the future. Journal of Teacher Education for Sustainability, 21(1), 5-34.

Pajares, F. (2003). Self-efficacy beliefs, motivation, and achievement in writing: A review of literature. Reading and Writing Quarterly, 19, 139-158. Retrieved from https://www.uky.edu/ eushe2/Pajares/Pajares2003RWQ.pdf

Pajares, F., Hartley, J., \& Valiante, G. (2001). Response format in writing self-efficacy assessment: Greater discrimination increases prediction. Measurement and Evaluation in Counseling and Development, 33(4), 214.

Paksoy, E. E. (2017). Kültürel değerlere duyarli ĕgitim bağlaminda öğretmen deneyimlerinin incelenmesi [Examination of teacher experiences in context of culturally responsive teaching]. (Unpublished doctoral dissertation), Gazi Universitesi, Ankara.

Paris, D. (2012). Culturally sustaining pedagogy: A needed change in stance, terminology, and practice. Educational Researcher, 41(3), 93-97. doi: 10.3102/0013189X12441244

Paris, D., \& Alim, H. S. (2014). What are we seeking to sustain through culturally sustaining pedagogy? A loving critique forward. Harvard Educational Review, 84(1), 85-100. doi: 10.17763/haer.84.1.9821873k2ht16m77

Paris, D., \& Alim, H. S. (2017). Culturally sustaining pedagogies: Teaching and learning for justice in a changing world. New York: Teachers College Press.

Polat, I., \& Kilic, E. (2013). Multicultural education in Turkey and teachers' competencies in multicultural education. YYU Journal of Education, 10(1), 352-372. Retrieved from http://dergipark.gov.tr/download/article-file/379842

Republic of Turkey Ministry of Interior Directorate General for Migration Management. (2018). Migration Statistics. Retrieved from http://www.goc.gov.tr/icerik/migrationstatistichs_915_1024

Ritosa, A. (2017). Interventions supporting mathematics and science in-service and pre-service teachers' cultural responsiveness. A Systematic Literature Review from 1995-2017. Retrieved from https://www.diva-portal.org/smash/get/diva2:1104961/ FULLTEXT01.pdf

Siwatu, K. O. (2007). Preservice teachers' culturally responsive teaching self-efficacy and outcome expectancy beliefs. Teaching and Teacher Education, 23(7), 10861101. Retrieved from https://doi.org/10.1016/j.tate.2006.07.011

Siwatu, K. O., Chesnut, S. R., Alejandro, A. Y., \& Young, H. A. (2016). Examining preservice teachers' culturally responsive teaching self-efficacy doubts. The Teacher Educator, 51(4), 277-296. Retrieved from https://doi.org/10.1080/08878730.2016. 1192709

Siwatu, K. O. (2008). Teaching in the era of no child left behind: Preservice teachers' self-efficacy beliefs and teaching concerns. Multicultural Learning and Teaching, 3(2), 30-47. Retrieved from https://doi.org/10.2202/2161-2412.1034

Siwatu, K. O. (2011). Preservice teachers' culturally responsive teaching self-efficacyforming experiences: A mixed methods study. The Journal of Educational Research, 104(5), 360-369. 
Siwatu, K. O., Putman, S. M., Starker-Glass, T. V., \& Lewis, C. W. (2015). The culturally responsive classroom management self-efficacy scale: Development and initial validation. Urban Education, 52(7), 862-888.

Siwatu, K. O., Polydore, C. L., \& Starker, T. V. (2009). Prospective elementary school teachers' culturally responsive teaching self-efficacy beliefs. Multicultural Learning and Teaching, 4(1), 1-15. doi: org/10.2202/2161-2412.1040

Sleeter, C. (2011). An agenda to strengthen culturally responsive pedagogy. English Teaching Practice and Critique, 10(2), 7-23. Retrieved from https://files.eric.ed.gov/ fulltext/EJ944889.pdf

Strekalova-Hughes, E., \& Wang, X. C. (2019). Perspectives of children from refugee backgrounds on their family storytelling as a culturally sustaining practice. Journal of Research in Childhood Education, 33(1), 6-21. Retrieved from https://doi.org/ 10.1080/02568543.2018.1531452

Stites, M. L., Rakes, C. R., Noggle, A. K., \& Shah, S. (2018). Preservice teacher perceptions of preparedness to teach in inclusive settings as an indicator of teacher preparation program effectiveness. Discourse and Communication for Sustainable Education, 9(2), 21-39. Retrieved from https://doi.org/10.2478/dcse-2018-0012

Tabachnick, B. G., \& Fidell, L. S. (2001). Using multivariate statistics (4 ${ }^{\text {th }}$ ed.). New York, NY: HarperCollins.

Tezel-McCarthy, A. (2018). Politics of refugee education: Educational administration of the Syrian refugee crisis in Turkey. Journal of Educational Administration and History, 50(3), 223-238. doi: 10.1080/00220620.2018.1440541

Tuncel, G. (2017). Improving the cultural responsiveness of prospective social studies teachers: An action research. Educational Sciences: Theory \& Practice, 17(4), 13171344. Retrieved from http:/www.estp.com.tr/wp-content/uploads/2017/04/20174-0269.pdf

UNHCR (2018). Registered Syrian Refugees in Turkey. Retrieved from https://data2. unhcr.org/en/situations/syria/location/113

Vass, G. (2017). Preparing for culturally responsive schooling: Initial teacher educators into the fray. Journal of Teacher Education, 68(5), 451-462. Retrieved from https://doi.org/10.1177\%2F0022487117702578

Villegas, A., \& Lucas, T. (2002). Preparing culturally responsive teachers: Rethinking the curriculum. Journal of Teacher Education, 53(1), 20-32. Retrieved from https://doi.org/10.1177/0022487102053001003

Warren, C. A. (2018). Empathy, teacher dispositions, and preparation for culturally responsive pedagogy. Journal of Teacher Education, 69(2), 169-183. Retrieved from https://doi.org/10.1177\%2F0022487117712487

Williams, D. L., Edwards, B., Kuhel, K. A., \& Lim, W. (2016). Culturally responsive dispositions in prospective mathematics teachers. Discourse and Communication for Sustainable Education, 7(2), 17-33. Retrieved from https://doi.org/10.1515/ dcse-2016-0013

Correspondence relating this article should be addressed to Nihat Kotluk, Independent Researcher, Turkey, Educational Sciences, Curriculum, Instruction, and Culture, tel: +905419087196. Email: nihatkotluk@gmail.com 